\title{
The Key Role of Storytelling in the Branding Process
}

\author{
Lecturer Meda MUCUNDORFEANU, PhD \\ Department of Communication, Public Relations and Advertising \\ Faculty of Political, Administrative and Communication Sciences \\ Babeș-Bolyai University, Cluj-Napoca, Romania \\ E-mail: mucundorfeanu@fspac.ro
}

\begin{abstract}
The branding process no longer revolves just around the main branding elements, such as naming, slogan, visual identity or positioning, but is rather a storytelling process promising customers the satisfaction of their needs, as well as an entirely new experience. Stories have a great persuasive force because our episodic memory stores them effortlessly and brings them back to us when we see or hear about the product again, unlike numbers and specific data (Wala 2015, p. 170). Therefore, products that tell stories are no longer foreign to consumers, since they know a great deal about them and products people associate with emotions and stories are called brands. The present paper offers an insight into this branding approach by combining theoretical considerations with numerous examples of brands which have already embraced this technique, with the aim of providing a better understanding of the process of storytelling in general and an assessment of its role, especially in relation to branding.
\end{abstract}

Keywords: Brand; branding; Story-branding; Storytelling; Persuasion. 


\section{Introduction}

"Brand" and "branding" are some of the most prolific terms used in specialized literature by practitioners and theoreticians alike. However, we should keep in mind that "brand" is a very complex concept and "branding" is an ever-evolving process, adapting to change and to the needs of the market, just as the advertising process itself.

Our paper defines these concepts and classifies the main strategies essential for the understanding of brands, while discussing concrete examples. One of the presented strategies consists of the use of storytelling. This is a technique with an increasing popularity, to such an extent that it has led to the formation of a new concept in specialized literature (Boje \& Khan 2010, p. 10), that of "Story-Branding".

The constant evolution of this field corroborates the fact that on such crowded markets, companies need to adapt and adopt innovative strategies in order to appeal to the customers and sell their products.

\section{Concept Definition and Characteristics}

\subsection{Brand and Branding}

According to Fanning (1999, p. 3), the classic definition of a brand was published in 1955 in the Harvard Business Review by B. V. Gardner and S. J. Levy, as follows: "A brand name is more than a label employed to differentiate among the manufacturers of a product. It is a complex symbol that represents a variety of ideas and attributes. It tells the customer many things - not only by the way it sounds (and its literal meaning if it has one), but more important by the body of associations it has built up and acquired as a public object over a period of time. The net result is the public image, the character or personality that may be more important for the overall status (and sales) of the brand than many technical facts about the product."

Other definitions refer to this concept in a more general and comprehensible manner. Green (2009, p. 32) defines the term "brand" as the sum of all feelings, thoughts, images, history, opportunities and market rumors that manifests itself in relation to a particular sector, group, company, product, service, idea or person; the sum of all the details communicated by an entity and the associations that can be made with it.

Wally Olins (2009), one of the most famous experts in the field, defines "branding" as a management activity, a complex, polyvalent and multidisciplinary process. He considers branding to be characterized by several fundamental specifications such as:

- a marketing, design, communication and human resources instrument;

- an activity which should always have an impact on every part of the organization and on each audience of the organization; 
- a coordination resource, because it makes the organizations' activities more coherent;

- above all, he considers that branding makes the strategy of the organization more visible and clearer for each of the audiences (Olins 2009, p. 21).

In short, it is the channel through which a company presents itself internally, to its own employees, and also to the various external media. It has an impact on every aspect and on each component of the company, as well as on all its audiences.

Looking at the definitions above we may conclude that everything is a brand, not only world famous products or companies, such as Nike and Adidas, but also, for example, the Grigore Antipa Museum in Romania.

Even Romania is a brand or at least advertising agencies and groups of advertisers and brand managers have been appointed by the Ministry of Tourism over the years to implement several branding campaigns, which have enjoyed moderate degrees of success (Abrudan, Mucundorfeanu 2009). The Grigore Antipa National Museum of National History is the first museum in Romania to benefit from a professionally integrated communication campaign, created by Leo Burnett \& Target in 2004 and successfully continued after the museum's re-opening in 2011 (Tomiuc in Balaban et al. 2015, p. 132). The reason they can all be regarded as brands is that the sum of what people think when hearing about these four names is a mixture of fact, randomness, impressions and emotions. The more favorable the overall impression of people towards products or services, the more likely they are to buy them - whether it is clothing articles in sports shops, investment opportunities in countries or tickets at the museum (Fanning 1999, p. 4).

Brands can be managed responsibly or not. For example, the above-mentioned brands Nike and Adidas are managed in such a way that last year, in 2017, they were placed on the first, respectively on the third place in a ranking regarding the most valuable sports business brands worldwide ${ }^{1}$. The brand managers of the Romanian Museum might not have the same resources as the above-mentioned moguls, but they have managed to develop quite a distinctive image in their respective markets over the past two decades.

\subsection{Storytelling}

The term "storytelling" has now probably reached the peak of its popularity in social sciences. There is a great interest for this subject, although it is not a new concept or practice. Its use and effects have been analyzed in various fields, such as anthropology, psychology or neuroscience.

1 https://www.statista.com/statistics/253349/brand-value-of-sports-businesses-worldwide/, (06.02.2018). 
The history of Storytelling probably began more than 40,000 years ago. This is the age of the oldest drawing in the world, the red disk of El Castillo (Sammer 2015 , p. 19). With the discovery of this old cave art in June 2012, the researchers who worked on this project managed to discover and decipher an entirely new world.

From the perspective of psychology, especially psychoanalysis, stories can be viewed as mental simulation rooms and mental experimental fields, which help patients to decipher and understand certain actions. Experts from the field of cognitive psychology claim that people remember stories 22 times better than pure facts (Sammer 2015, p. 27). Jerome Bruner, a specialist in the field of cognitive psychology, stresses in his book "Actual Minds, Possible Worlds" two types of world views: argumentative (logic-rational) and narrative thinking. According to his statement expressed as early as 1986, people understand the world around them not just through logical structures, but also with the help of examples expressed through stories and images (Wala 2015, p. 169). Brands attempt to address this second type of thinking, to break the routine in people's minds.

A similar view was expressed by Robert McKee, reputed screenwriting instructor and author of the standard reference work with the title "Story. Substance, Structure, Style and the Principles of Screenwriting". He identified two different techniques for bundling information in a meaningful way. The first one is rational and refers to listing and juxtaposing data and facts and the second one is emotional, through a story. In order to convince people of something through logical argumentation they have to be open, focused and willing to accept such a message. As soon as we meet someone who is not focused or not interested in the message a brand wants to tell, which is often the case, rational persuasion reaches its limits. Research on persuasion techniques has long proven that story-driven emotional convincing is far more efficient and successful than the mere enumeration of data and facts (Sammer 2015, pp. 5-6).

Even advertising practitioners openly describe their convictions regarding this process. Kevin Roberts, the CEO of the advertising agency Saatchi \& Saatchi, claimed that stories represent the decisive connection tool between people (Roberts 2008, p. 264). Hence, we can naturally assume that good stories could connect people to a brand as well. With the help of an interesting story, a brand can set itself apart from others, gain the attention of customers, deliver material for wordof-mouth and also offer an emotional added value (Wala 2015, p. 168).

Last but not least, neuroscientists have analyzed the effect narrations have on people's brains and have come to three main conclusions: stories activate areas in the brain responsible for speech, empathy and even pain; stories are felt throughout the entire body, because they trigger secretions of hormones that make people emotional; stories plant ideas into our heads and we make them our own; during 
a narration, the brains of the narrator and the listener synchronize (Sammer 2015, pp. 29-34). These facts prove that the human brain is especially susceptible to narrations.

\subsection{Story-Branding}

Specialized literature has created and defined a new term consisting of the terms explained before. The concept of "story-branding" refers to "entrepreneurs strengthening their brands by putting into play a characterization of events relating to a CSR initiative in the Third World that ends up branding one set of actors (entrepreneurs and their organizations) as heroes who rescue other characters. The focus of this form of storytelling is on the entrepreneur as hero in an adventurous story saga." (Boje \& Khan 2010, p. 10). In other words, this term refers to the fact, that sometimes companies tell one-sided stories about their actions, in order to appeal to the audiences and gain a boost of image. They either exaggerate their contributions or do not offer the whole picture, in order to brand themselves as socially responsible actors. This might be considered one step too far in the use of narratives with the purpose of achieving one's goals.

\section{Stories Told by Brands}

Looking at the thoughts expressed above, we may consider that storytelling can be viewed as the distinctive element that can make the difference between responsible and irresponsible brand management. Well-managed brands have a story at their core, which is consistent with its core values. Telling a story is not a guarantee for success, it is also important to know what kind of story to tell and in which manner.

Hermann Wala (2015, pp. 175-176) suggests several situations which almost every company has experienced and which can be used as a starting point for successful stories if they are added a little twist:

-the founding history of the company;

- pioneering inventions;

- crises and how they were overcome;

- unusual successes;

- unusual or surprising facts about their products (how they were created, the origin of their name, what contributed to their success);

-employees one can be proud of;

-top managers who support the values of companies even in delicate situations;

-endearing weaknesses or mistakes of well-known decision-makers;

- customers who can rely on the product in critical situations;

-unusual or particularly prominent customers. 
Stories offer experiences and identification possibilities, a surplus value that makes a brand emotionally charged and makes it interesting and attractive for customers.

Many times storytelling is used by focusing on a specific element which lies at the core of a brand. This core element of the brand is highlighted and transformed into the main character in the story which helps promote that brand. Some of the most common stories revolve around the following three aspects:

-the shape of the product

-family tradition

- reference to historical events (Mucundorfeanu 2017, pp. 35-39).

We shall describe and explain these three aspects, by using examples of wellknown brands and their stories, famous especially in the German speaking areas. The brands used as examples are the chocolate bars Mars and Ritter Sport, the baby food producer Hipp and the German manufacturer of luxury writing instruments, watches and leather goods Montblanc. The list of examples will be completed by two more: Guiness and Mon Cheri. These two brands have found unusual ways of presenting themselves through stories told in manners not used before by other brands.

We have chosen these brands because they are well-known for their high quality, as well as for the stories they are telling. As theirs were only one of the many products in their sector, their brand managers have figured out that in order for them to be remembered, they have to be distinctive. These brands tell and keep on telling the same story in different manners on each platform where they are promoted. By telling a consistent story about their shape, history or ingredients, these brands have gained personality, ensuring their memorability and a higher chance of being distinguished form their competition.

\subsection{The Shape of the Product}

Invented by the American company 'Mars, Inc.' in 1967, the Twix bar was initially called Raider and had the purpose of pleasing the British princes' love for tea and cookies.' In 1979, when Twix was launched onto the US market, it was renamed into Twix because Raider is synonymous with robber or bandit (Puttenat 2009 , p. 30). The greatest competitor was KitKat and Twix had to create a strong strategy in order to establish the chocolate bar as a brand on the market. With the help of the advertising agency BBDO, the company created a strong story at the core of the product and even nowadays everything revolves around it: "Twix company has shared the details of its troubled past, shedding light on the question of candy

2 http://twixorigin.weebly.com/background.html, (25.04.2017). 
bar bifurcation. It seems that almost immediately after Twix was unveiled, the company's two like-minded founders - Seamus and Earl-fell into an abyss of irreconcilable disagreement. Realizing that they could no longer continue on as co-workers, they decided to split the company in two. What emerged from the division were two rival companies alike in nearly every way, Left Twix and Right Twix. While obvious to the outside world, the overwhelming similarities between the two chocolaty corporations went unnoticed by the myopic executives of each respective "side". According to the ad's narrator, each factory took a vastly different approach. Left Twix flowed caramel on cookie, while Right Twix cascaded caramel on cookie. Left Twix bathed in chocolate, while Right Twix cloaked in chocolate."3 The two apparently different chocolate sticks are packaged by the Twix Union Packaging Company. The entire official website twix.com is constructed around this story and consumers have to decide between right and left. This invented story builds brand awareness, gives the product an identity and has succeeded in increasing sales and making the brand globally famous.

"Square, practical, good" 4 is the selling line of the chocolate Ritter Sport. Here everything revolves around the square shape of the product. Brought on the market almost one hundred years ago, Ritter Sport differentiates itself from the competition through its practical shape. The chocolate producer had the idea of producing chocolate bars for athletes, who need a boost of energy from time to time, and therefore made them into a square shape in order to fit into the pockets of sports jackets. This idea helped the company to achieve a unique positioning in the consumers' minds and to become one of the best-selling chocolate brands in Germany (Mucundorfeanu 2017, p. 36).

\subsection{Family Tradition}

The Hipp GmbH \& Co. KG is a German organic baby food company and was founded in 1899 by Joseph Hipp. The story behind its products is available on the official website. ${ }^{5}$ Having a baby, Joseph Hipp, who was a baker at the time, created a natural baby food option, a solution between breastfeeding and "real food". Several years later, after many people found out about his natural recipes, his son Georg Hipp took his father's idea to the next level and opened a business in their hometown, Pfaffenhofen. Together with a Swiss doctor they invented new baby food recipes and converted their family-run farm into an organic one, becoming the proud producers of organic and natural ingredients, which are still used today in the Hipp jars and bottles. After the death of Georg Hipp, his son, Claus, took over the family business. Claus Hipp is the famous figure appearing in every Hipp

3 http://libertyblog.org/2013/07/politwix-are-left-and-right-really-different/, (25.04.2017)

4 Original selling line in German: "Quadratisch, praktisch, gut".

5 https://www.hipp.de/ueber-hipp/unternehmen/historie/, (25.04.2017). 
TV ad, assuring us of the quality of his products with the famous sentence: "I vouch for it with my name" ${ }^{\prime \prime}$, which is a promise and a guarantee for all customers given directly by Mr. Hipp himself, not only as the owner of the company, but also as a bio-pioneer.

By using Claus Hipp as a trustworthy testimonial and a consistent visual image in the advertisements the storytelling of Hipp activates the customers' sense of trust in the brand. In recent years, the son of Claus Hipp, Stefan, has appeared in some advertisements, continuing the family tradition and being the fourth generation vouching for the quality of their products, gaining the trust of parents all over the world (Mucundorfeanu 2017, p. 37).

\subsection{Reference to Historical Events}

A brand who had famous ambassadors without even planning it is Montblanc. During the course of history, several presidents used the pen publicly, when signing important treaties, making it even more famous and connecting it to relevant historic moments. "May I help you, Mr Adenauer?" is the sentence used by John F. Kennedy in 1963 during a visit to Berlin when the German chancellor Konrad Adenauer wanted to sign the Golden Book of Berlin and did not have a pen. Kennedy offered him his "Meisterstück" from Montblanc ${ }^{7}$. In recent years, the company has even created a special edition pen, in dark blue, named after John F. Kennedy. ${ }^{8}$

Another unforeseen event happened when the president of France, Nicolas Sarkozy, had a meeting with the Romanian president, Traian Băsescu, in Bucharest in 2008. According to a video 9 , president Sarkozy was visibly fascinated by the Montblanc pen he was given to sign a treaty with. So after lingering for a few moments looking at the pen under the flashlights of the journalistic photographers, he whispered something to the Romanian president and after receiving a sign of approval, he gladly took the pen and put it in his jacket pocket.

In their most recent presentation video ${ }^{10}$ starring Hugh Jackman, Montblanc makes reference to the fact that they have written history, claiming that world leaders used the "Meisterstück" to sign treaties and great writers to draft ground breaking novels. These and other similar events have helped Montblanc reach worldwide notoriety and a high status in the minds of consumers.

6 Original selling line in German: "Dafür stehe ich mit meinem Namen".

7 http://www.montblanc.com/en/discover/history.html, (25.04.2017).

8 http://www.montblanc.com/en/collection/writing-instruments/great-characters-edition/ 111045-john-f_-kennedy-special-edition-fountain-pen.html, (26.04.2017).

9 https://www.youtube.com/watch?v=mZCSS4uEscQ, (25.04.2017).

10 https://www.youtube.com/watch?v=kBz796Ja7t8, (25.04.2017). 


\subsection{Long Stories}

From youngest to oldest, all people love to hear stories. And when brands tell them, they immediately gain sympathy and have more chances of being chosen than their competition, even if just for the sake of telling the story to others while enjoying the product. (Mucundorfeanu 2017, p. 33). Many brands tell unusual stories but out of all of them, Guinness is well known for their unconventional stories. One of the most ingenious and long-lasting campaigns ${ }^{11}$ started in the 1950s and is still going on today. In 1959, 150,000 specially embossed bottles were dropped into the Atlantic Ocean. The bottles were sealed with a lead capping to protect the small number of documents they contained, the most interesting of these being a colorful certificate from the Office of King Neptune containing the following text ${ }^{12}$ :

"To the finder of this document greetings and let it be known to all men (and women) that I, Neptune, Monarch of the Sea, have permitted the House of Guinness to cast in, and/or, upon my Domain the bottle carrying this document - but in precise particular, the Atlantic Ocean - and allow same free passage, without let or hindrance, to convey to you the story of Guinness Stout, as also to further the fascinating hobby of labology (the collecting of bottle labels). All regular collectors will find the enclosed label - of the world's most famous Stout - a valuable one to add to their collection, especially when it is realized that this particular issue was made in the bi-centenary year of the House of Guinness and that it was strictly limited and will never be reprinted as such. Truly a rare and unique label! If you, or any of your friends, would like specimens of other Guinness Stout labels please write: Guinness Exports Ltd, Atlas Street, Liverpool, England. But, in any case, do please try a bottle of Guinness Stout, I am sure you will appreciate it, just as Guinness Exports Ltd. will appreciate hearing from you. Neptune"

These bottles are still turning up 50 years after the event, making it the longest running Guinness campaign and one of the longest campaigns ever. Many finders are fascinated ${ }^{13}$ by the messages they found in the bottle and are spreading the word about this brand on- and offline.

\subsection{Exquisite Ingredients}

Another example is the brand Mon Cheri, which is a chocolate producer selling chocolate candies with a cherry placed in the liqueur filling, something not very unusual or new, tells their customers a story about those cherries. The Brand of Ferrero founded in 1946 in Alba, Piedmont, introduced and patented the Pied-

11 http://www.guinntiques.com/thebottledrop.aspx, (06.02 2018).

$12 \mathrm{http}: / /$ www.guinntiques.com/thebottledrop.aspx, (06.02 2018).

13 https://messageinabottlehunter.com/a-guinness-record/, (07.02.2018). 
mont Cherry as a marketing invention. ${ }^{14}$ Cherries from Piedmont are of high quality, but the harvest of cherries in that region is very small, it would not be enough for all the chocolates produced and sold during the winter season ${ }^{15}$. But the production takes place in Piedmont, where the cherries are kept in perfect conditions, until they are used in the chocolate. The legend of the cherry in Mon Cherry makes this product unique and is part of its exquisiteness.

\section{Considerations Based on Empirical Evidence}

The fact that stories are not only pleasant to hear, but can also bring financial added value if connected to products for sale, has been proved by Joshua Glenn and Rob Walker. They conducted an impressive literary and anthropological experiment on their website ${ }^{16}$ through which they demonstrated that the effect of narrative on any given object's subjective value can be measured objectively.

To be more precise, they bought several objects from flea markets for $\$ 1.25$ apiece on average and sold them on eBay for nearly $\$ 8,000.00$ in total. They managed to do so through storytelling. The item descriptions on the Internet platform were substituted by short stories purpose-written by over 200 contributing writers. To name just one example, they bought a small red cooking fork for 50 cents and managed to sell it for $26 \$$ with the help of a story told by the novelist Dan Chaon. The short story was told from the perspective of a widower, who, while looking at the crease in his finger caused by his wedding ring, which he wore his entire life, remembered about this little red fork that he stole when he was young and never told his wife about. The story ends with him thinking that the fork was now probably in the right place, back where it came from. All the projects' stories can be found on their website and a collection of 100 of the project's finest stories was later published in a book available online. The objects sold during the experiment were not depicted to be something else than they actually were. No one claimed that they belonged to famous persons or that they were involved in historic events, the strategy was simply to stress through narrative techniques the importance they had (and can have) to someone at a certain point in their lives.

The previous experiment stresses the importance of creative writing, but we must bear in mind that not every story appeals to everyone. People's expectations based on previous experience have a great role in this regard as well. The more a person can relate to a story, due to previous experience and expectations, the

14 https://www.welt.de/reise/article7347959/Die-grosse-Luege-um-die-Piemont-Kirsche.html, (06.02, 2018).

15 http://www.spiegel.de/wirtschaft/kirschexpertin-claudia-bertani-die-ewige-suche-nach-derpiemont-kirsche-a-442035.html, (06.02. 2018).

16 http://significantobjects.com/, (07.02.2018). 
higher the chance that it will appeal to him or her. Psychologist Melanie C. Green from the University of North Carolina at Chapel Hill has discovered that for people who experienced a similar situation or something related to the situation described in a story, the immersion in the story is greater than for those who did not live through such an experience and therefore find it harder to relate to it. Consequently, the power of persuasion is greater when it comes to the first category (Hsu 2008, p. 1). For the branding process these findings translate into the necessity of a good understanding of the audience the brands are addressing.

\section{Conclusions}

Based on the examples, the experiments and the literature review presented above, we may formulate a few general observations concerning the branding process.

Stories have a great persuasive force because our episodic memory stores them effortlessly and brings them back to us when we see or hear about the product again, unlike numbers and specific data (Wala 2015, p. 170). Therefore, products which tell stories are no longer foreign to consumers, since they know a great deal about them and products people associate with emotions and stories are called brands. Telling just any story would not have a lasting impact, because the content of the narrative, as well as the style, are fundamental. The starting point of the story should be an item present at the core of the brand, it should describe the brand and be in tune with its values. It is also crucial that such narratives should not be used for image boosting at any cost. Ethical factors have to be always taken into consideration.

The experiments described in the previous chapter proved that storytelling can set and even measure the value of a product. Told in a witty manner, by someone who has the talent to do so, simple stories can have great power especially upon those audiences that can be immersed into them due to their previous life experience.

This study is of exploratory nature with the aim of a better understanding of the process of storytelling in general and an assessment of its role especially in relation to branding. It has taken into consideration some of the formulated theories, definitions and research that has been carried out on the matter in different fields and has provided several examples from the field of advertising and branding, in order to provide a larger picture. The ideas presented are by no means an exhaustive elaboration of the theoretical and empirical potential, but the findings can be taken into consideration for further research on the matter. 


\section{References}

1. Abrudan, Mirela-Codruta, Mucundorfeanu, Meda (2009). Brand and Nation Branding in the Case of Romania. Journal of Media Research, no. 5/2009: 89-101.

2. Boje, M. David, Khan, R. Farzad (2009). Story-Branding by Empire Entrepreneurs: Nike, Child Labour and Pakistan's Soccer Ball Industry. Journal of Small Business and Entrepreneurship, vol. 22, Issue No. 1.

3. Tomiuc, Anamaria (2015). Mediatization of Culture. Audience, Branding and the Contemporary Museum in Romania. In Balaban, Cristina Delia, Hosu Ioan, Mucundorfeanu Meda (2015). PR Trend. Developments and Trends in Communication, Hochschulverlag Mittweida, Mittweida, Germania, ISBN: 978-3-9815142-5-4.

4. Fanning, John (1999). Tell Me a Story: The Future of Branding. Irish Marketing Review, vol. 12, no. 2, ColourBooks, Dublin.

5. Green, Andy (2009). Comunicarea eficientă în relațiile publice, Polirom, Iași.

6. Hsu, Jeremy (2008). The Secrets of Storytelling: Why We Love a Good Yarn. Scientific American Mind, Issue 18, Retrieved from: https://www.scientificamerican.com/ article/the-secrets-of-storytelling.

7. Mucundorfeanu Meda (2017). The Creative Process Behind the Advertising Discourse, Hochschulverlag Mittweida, Mittweida, Germania, ISBN: 978-3-9815142-8-5.

8. Olins, Wally (2009). Manual de branding, Editura Vellant, București.

9. Puttenat, Daniela (2009). Praxishandbuch Krisenkommunikation: Von Ackermann bis Zumwinkel: PR Störfälle und ihre Lektionen, Gabler Verlag, Wiesbaden.

10. Roberts, Kewin (2008). Der Lovemark/Effekt. Markenloyalität jenseits der Vernunft, miWirtschaftsbuch, Munich.

11. Sammer, Petra (2015). Storytelling. Die Zukunft von PR und Marketing, dpunkt. verlag, Heidelberg.

12. Wala, H. Hermann (2015). Meine Marke. Was Unternehmen authentisch, unverwechselbar und lagfristig erfolgreich macht, 7.th updated edition, Redline Verlag, Munich.

\section{Online Sources}

13. https://www.statista.com/statistics/253349/brand-value-of-sports-businessesworldwide/, (06.02.2018).

14. http://twixorigin.weebly.com/background.html, (25.04.2017).

15. http://libertyblog.org/2013/07/politwix-are-left-and-right-really-different/, (25.04.2017).

16. https://www.hipp.de/ueber-hipp/unternehmen/historie/, (25.04.2017).

17. http://www.montblanc.com/en/discover/history.html, (25.04.2017).

18. http://www.montblanc.com/en/collection/writing-instruments/great-charactersedition/111045-john-f_-kennedy-special-edition-fountain-pen.html, (26.04.2017).

19. https://www.youtube.com/watch?v=mZCSS4uEscQ, (25.04.2017).

20. https://www.youtube.com/watch?v=kBz796Ja7t8, (25.04.2017).

21. http://www.guinntiques.com/thebottledrop.aspx, (06.02 2018). 
22. http://www.guinntiques.com/thebottledrop.aspx, (06.02 2018).

23. https://messageinabottlehunter.com/a-guinness-record/, (07.02.2018).

24. https://www.welt.de/reise/article7347959/Die-grosse-Luege-um-die-Piemont-Kirsche.html, $(06.02,2018)$.

25. http://www.spiegel.de/wirtschaft/kirschexpertin-claudia-bertani-die-ewige-suchenach-der-piemont-kirsche-a-442035.html, (06.02. 2018).

26. http://significantobjects.com/, (07.02.2018). 